\title{
Pilomatrixoma of the Posterior Cervical Region
}

\author{
Sedat Aydın, ${ }^{1}$ Mehmet Gökhan Demir, ${ }^{2}$ \\ Muhammet Ali Özçelik, Sevinç Hallaç Keser ${ }^{3}$
}

'Department of Otolaryngology, Kartal Dr. Lütfi Kırdar Training and Research Hospital, İstanbul Turkey

${ }^{2}$ Department of Otolaryngology Etimesgut State Hospital, Ankara, Turkey

${ }^{3}$ Department of Pathology, Kartal Dr. Lütfi Kırdar Training and Research Hospital, İstanbul Turkey

Submitted: 08.10.2016 Accepted: 13.07.2017

Correspondence: Mehmet Gökhan Demir Etimesgut Devlet Hastanesi, Etimesgut, 06800 Ankara, Turkey E-mail:mgokhandemir@yahoo.com

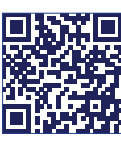

Keywords: Cervical region, neck; pilomatrixoma.

\section{Dear Editor,}

Pilomatrixoma, also known as Malherbe's calcifying epithelioma, originates in pluripotent precursor cells of the hair follicles. The tumor was first mistakenly described by Malherbe and Chenanatis as a benign tumor of the sebaceous gland, then later recognized as related to the hair follicles. ${ }^{[1]}$

Pilomatrixoma is a slow-growing, dermal tumor, usually found on the head and neck region, and less frequently on the trunk and lower extremities. Most cases are detected in children and young adults, with a female predominance, but it may be seen at any age and in either gender. ${ }^{[2]}$

Clinically, pilomatrixoma typically presents as a painless, solitary, superficial, mobile lesion that easily slides over the underlying subcutaneous tissue. An irregular, hard structure can be palpated when there is significant calcification. A blue discoloration may indicate ulceration of the mass. Other characteristic features of the lesion are an average size of $10 \mathrm{~mm}$ or less, consistency ranging from firm to cystic, moderate pattern of growth, pink to purple hue with sub-epithelial yellowish tinge, and intact overlying skin with telangiectasic vessels.

Differential diagnosis should include epidermoid cyst, dermoid cyst, sebaceous adenoma or carcinoma, juvenile xanthogranuloma, capillary hemangioma, chalazion, and rhabdomyosarcoma. ${ }^{[3-5]}$ Although pilomatrixoma grows slowly, it occasionally demonstrates rapid growth and can resemble keratoacanthoma of the skin. ${ }^{[6]}$

Ultrasonography (US) investigation is helpful to detect pilomatrixoma. ${ }^{[7]}$ The accuracy rate for a round, well-demarcated, hyperechogenic mass with a dense posterior acoustic shadow is approximately $80 \% .{ }^{[8]}$ US examination and findings of expected features can confirm the diagnosis. Computer tomography and magnetic resonance imaging examinations also provide more detail of surrounding structures and the depth of the lesion.

Fine needle aspiration biopsy (FNAB) may reveal diagnostic clues for diagnosis of pilomatrixoma, but can also lead to misdiagnosis of carcinoma and result in aggressive surgery. ${ }^{[9]}$ In a previous study, the diagnostic accuracy of FNAB for pilomatrixoma was found to be $44.4 \% .^{[10]}$

Histopathologically, pilomatrixoma has sharply demarcated dermal nodules surrounded by a capsule of fibrous tissue located in the dermis, extending into the subcutaneous fat. Shadow cells, also known as ghost cells, which evolve from basaloid cells, are dead cells that retain their cellular shape and appear as a central, unstained area that corresponds to the lost nucleus. The tumor often has calcification structures around the ghost cells, and there may be foreign body giant cells around the keratinized debris.

Pilomatrixoma will not spontaneously regress, so surgical excision of the tumor and the 


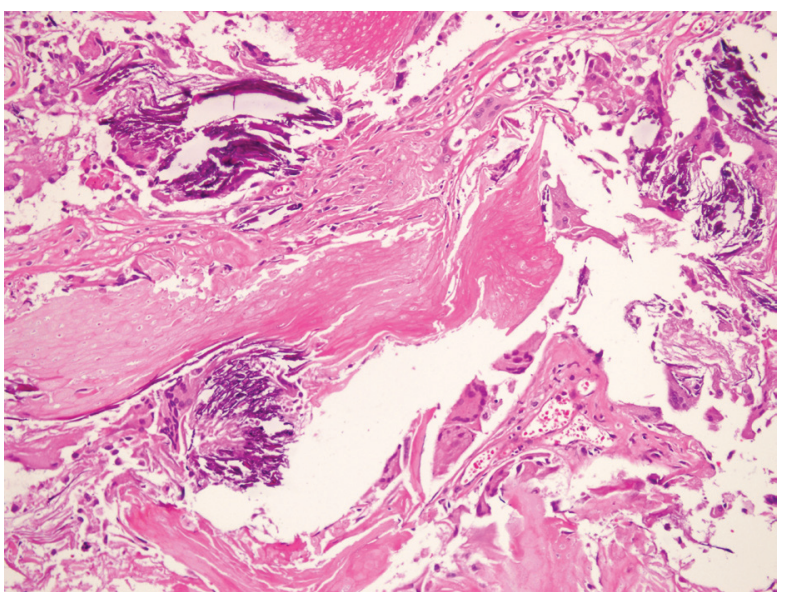

Figure 1. Pilomatrixoma.

overlying skin is the primary treatment modality. After total excision of the tumor, the recurrence rate varies from $1.5 \%$ to $6 \% .{ }^{[1,12]}$ Malignant transformation is only rarely reported, typically a low grade tumor, with higher recurrence potential in elderly patients. ${ }^{[13]}$

A 20-year-old male patient presented at our clinic with a mobile, slow-growing, asymptomatic $2 \times 2 \mathrm{~cm}$ lesion, firm and cystic in appearance, on the posterior cervical triangle of the neck. Pathological examination revealed a solid, well-demarcated, tumoral lesion surrounded by fibrous pseudocysts. The tumor was composed of small, round, uniform, vesicular nuclei, and study of the nuclei revealed basaloid cells and ghost cells with eosinophilic appearance. The diagnosis was pilomatrixoma (Figure I). No recurrence has been detected since excision in I year of follow-up.

Pilomatrixoma is a rare, benign form of dermal tumor, most often seen in females and adolescents, but one that may appear at any age and in either gender. Treatment is total excision. The differential diagnosis can be confusing for the clinician. Keep pilomatrixoma in mind when a firm, mobile, dermally located lesion is detected in the head and neck region.

Peer-review

Internally peer-reviewed.
Authorship Contributions

Concept: S.A., M.G.D., M.A.Ö., S.H.K.; Design: S.A., M.G.D., M.A.Ö., S.H.K.; Data collection \&/or processing: S.A., M.G.D., M.A.Ö., S.H.K.; Literature search: M.G.D.; Writing: S.A., M.G.D., M.A.Ö., S.H.K.

Conflict of Interest

None declared.

\section{REFERENCES}

1. Lever W, Griesemer RD. Calcifying epithelioma of Malherbe; report of 15 cases, with comments on its differentiation from calcified epidermal cyst and on its histogenesis. Arch Derm Syphilol 1949;59:506-18. [CrossRef]

2. Julian CG, Bowers PW. A clinical review of 209 pilomatricomas. J Am Acad Dermatol 1998;39:191-5. [CrossRef]

3. Yap EY, Hohberger GG, Bartley GB. Pilomatrixoma of the eyelids and eyebrows in children and adolescents. Ophthal Plast Reconstr Surg 1999;15:185-9. [CrossRef]

4. Shields JA, Shields CL, Eagle RC Jr, Mulvey L. Pilomatrixoma of the eyelid. J Pediatr Ophthalmol Strabismus 1995;32:260-1.

5. Perez RC, Nicholson DH. Malherbe's calcifying epithelioma (pilomatrixoma) of the eyelid. Clinical features. Arch Ophthalmol 1979;97:314-5. [CrossRef]

6. Kang HY, Kang WH. Guess what! Perforating pilomatricoma resembling keratoacanthoma. Eur J Dermatol 2000;10:63-4.

7. Fink AM, Berkowitz RG. Sonography in preauricular pilomatrixoma of childhood. Ann Otol Rhinol Laryngol 1997;106:167-9. [CrossRef]

8. Choo HJ, Lee SJ, Lee YH, Lee JH, Oh M, Kim MH, et al. Pilomatricomas: the diagnostic value of ultrasound. Skeletal Radiol 2010;39:243-50. [CrossRef]

9. Lemos MM, Kindblom LG, Meis-Kindblom JM, Ryd W, Willén $\mathrm{H}$. Fine-needle aspiration features of pilomatrixoma. Cancer 2001;93:252-6. [CrossRef]

10. Gupta M, Gupta V, Kumar R, Jhajj K. Pilomatricoma: Adiagnotic pitfall in fine needle aspiration cytology. Journal of Evolution of Medical and Dental Science 2014;3:1691-97. [CrossRef]

11. Pirouzmanesh A, Reinisch JF, Gonzalez-Gomez I, Smith EM, Meara JG. Pilomatrixoma: a review of 346 cases. Plast Reconstr Surg 2003;112:1784-9. [CrossRef]

12. Danielson-Cohen A, Lin SJ, Hughes CA, An YH, Maddalozzo J. Head and neck pilomatrixoma in children. Arch Otolaryngol Head Neck Surg 2001;127:1481-3. [CrossRef]

13. Sable D, Snow SN. Pilomatrix carcinoma of the back treated by mohs micrographic surgery. Dermatol Surg 2004;30:1174-6. [CrossRef] 